\title{
Progress of the IAHE Nuclear Hydrogen Division on International Hydrogen Production Programs
}

\author{
A. Odukoya ${ }^{1^{*}}$, G. F. Naterer ${ }^{2}$, M. Roeb ${ }^{3}$, C. Mansila ${ }^{4}$, J. Mougin ${ }^{5}$, B.Yu ${ }^{6}$, J. Kupecki ${ }^{7}$, \\ I. Iordache ${ }^{8}$, J. Milewski ${ }^{9}$ \\ 1, 2 Memorial University of Newfoundland, St. John’s, Newfoundland, Canada \\ ${ }^{3}$ German Aerospace Center, Institute of Solar Research, Koeln, Germany \\ ${ }^{4}$ Commissariat à l'Energie Atomique et aux Energies Alternatives (CEA), DEN, I-tésé, F-91191 Gif-sur-Yvette, France \\ ${ }^{5}$ Commissariat à l'Energie Atomique et aux Energies Alternatives (CEA), LITEN, F-38054 Grenoble, France \\ ${ }^{6}$ Tsinghua University, Beijing, China \\ ${ }^{7}$ Institute of Power Engineering, Poland \\ ${ }^{8}$ Romania Association of Hydrogen Energy, Romania
}

\begin{abstract}
This paper presents recent activities of the IAHE Nuclear Hydrogen Division and associated research advances in Canada, China, France, Germany, Poland, and Romania on programs and major initiatives on large-scale hydrogen production and utilization. Germany and France have made significant advances in high temperature steam electrolysis (HTSE). Germany has successfully demonstrated a 3-kW electrolyzer powered by solar energy. France demonstrated a 25-cell stack HTSE, which can produce $1.7 \mathrm{Nm}^{3} / \mathrm{hr}^{\text {of }}$ hydrogen. China has made significant progress in developing the Sulfur-Iodine cycle at a hydrogen production rate of $60 \mathrm{dm}^{3} / \mathrm{hr}$. A 10-cell HTSE was developed and tested at Tsinghua University, China. Romania is collaborating with Canada on nuclear hydrogen production with the thermochemical $\mathrm{Cu}-\mathrm{Cl}$ cycle. The individual unit operations of the $\mathrm{Cu}-\mathrm{Cl}$ cycle have been verified experimentally. Research on integration of a laboratory scale system to produce $3 \mathrm{~kg}$ of hydrogen per day is underway at the University of Ontario Institute of Technology in Oshawa, Ontario. Poland has developed advanced simulation capabilities for Solid Oxide Fuel/Electrolysis Cells for hydrogen peak energy storage as well as laboratory scale experiments focused on solid oxide and molten carbonate fuel cells. This paper presents a review of activities of members of the IAHE Nuclear Hydrogen Division in these six countries.
\end{abstract}

\footnotetext{
${ }^{1 *}$ Research Project Engineer, Faculty of Engineering and Applied Science, Memorial University, St. John’s, Newfoundland, 240 Prince Phillip Drive, St. John’s, NL Canada A1B 3X5, Email: aodukoya@mun.ca, Phone:1-709-864-2395, Fax: (709) 864-8975

${ }^{2}$ Professor and Dean, Faculty of Engineering and Applied Science, Memorial University of Newfoundland, St. John's, NL, A1B 3X5

${ }^{3}$ Team leader, German Aerospace Center, Institute of Solar Research, Koeln, Germany, 51147

${ }^{4}$ Researcher, Commissariat à l'Energie Atomique et aux Energies Alternatives, Gif-sur-Yvette, France

${ }^{5}$ Manager, Commissariat à l'Energie Atomique et aux Energies Alternatives, Grenoble, France

${ }^{6}$ Professor, Tsinghua University, Beijing, China

${ }^{7}$ Research Fellow, Institute of Power Engineering, Poland

${ }^{8}$ Romania Association of Hydrogen Energy, Romania

${ }^{9}$ Professor and Team Leader, Warsaw University of Technology, Institute of Heat Enegineering, Warsaw, Poland
} 


\section{Introduction}

Large-scale demonstration projects of sustainable hydrogen production require major investments by countries and long term strategies for production, transportation, usage, and storage of hydrogen. Among the various technologies available, hydrogen production can be achieved by electrolysis and thermochemical cycles. Several countries such as Canada, China, France, Germany, Poland, and Romania are investing in long-term programs toward a future hydrogen economy. This paper reports on recent developments in these countries for the advancement of programs and initiatives on commercial hydrogen production.

The main commercial method of producing hydrogen is steam methane reforming from natural gas. Researchers are investigating other possibilities of large-scale production to reduce the carbon footprint of processes that use fossil fuels. Electrolysis of water is also extensively developed as an alternative to steam methane reforming [1-3]. An increase in current density $\left(\mathrm{A} / \mathrm{cm}^{2}\right)$ reduces the size of the system and results in a decrease in investment cost. The efficiency of hydrogen production $\left(\mathrm{kWh} / \mathrm{Nm}^{3}\right)$ is typically inversely proportional to supply voltage for the electrolysis process. The most advanced technologies to date are systems using alkaline electrolytes and polymer electrolytes. For both technologies, $80 \%$ of the cost of producing a $\mathrm{kg}$ of $\mathrm{H}_{2}$ is due to the price of electricity. As indicated in Fig. 1, the prime objective is to increase the current density, while reducing the supplied voltage.

Hydrogen is expected to have a key role as an energy carrier for the transport sector and as an energy storage medium for the integration of renewable energy in the grid. The development of carbon clean technologies, which produce hydrogen from renewable or low $\mathrm{CO}_{2}$ emitting sources like nuclear energy, is also of importance. In the case of high temperature steam electrolysis (HTSE), less electricity is required to dissociate the water molecule at high temperatures. The additional heat required for dissociation is provided by waste heat, which is available at a reduced cost. Furthermore, the coupling of a heat source with HTSE allows the latter to reach high efficiency levels, which is an advantage over other electrolysis technologies

Increasing the system temperature in high temperature steam electrolysis reduces the electricity demand, due to the improved electrochemical kinetics. One of the limitations of the process involves issues of material properties at high temperature. This raises concern about the durability and safety of the system. Fig. 2 shows the voltage and current density comparison of three electrolysis processes: alkaline, PEM, and HTSE. The results indicate that HTSE is the most promising technology with a reduced voltage at higher current density. The alkaline and PEM electrolysis can produce hydrogen at a rate of 4 to $6 \mathrm{kWh} / \mathrm{Nm}^{3}$, while the HTSE produces hydrogen at a rate of $3.5 \mathrm{kWh} / \mathrm{Nm}^{3}$. One drawback of the HTSE is the higher cost of initial investment, which is expected to drop with advancement in technology. 
Thermochemical cycles and high temperature electrolysis are currently being developed for demonstration projects of large-scale hydrogen production from renewable energy source by countries discussed in this paper. This paper will highlight the progress in these various countries, specific technical challenges, and future directions of each country in the following sections.

\section{Canada}

In recent years, the copper-chlorine ( $\mathrm{Cu}-\mathrm{Cl})$ cycle (Fig. 3) has increasingly attracted the interest of researchers due to its lower temperature requirement $\left(530^{\circ} \mathrm{C}\right)$ than other thermochemical cycles [4-6]. Thermochemical water decomposition using the $\mathrm{Cu}-\mathrm{Cl}$ cycle generally involves three steps: hydrogen production, oxygen production and re-cycling of intermediate copper/chlorine compounds [7]. An important advantage of this cycle is that chemical reactions form a closed internal loop that re-cycles all chemicals on a continuous basis without emitting any greenhouse gases [8-10]. Long-term experiments of the $\mathrm{CuCl} / \mathrm{HCl}$ electrolysis process were demonstrated by Atomic Energy of Canada Limited (AECL) [11,12]. It was shown that the anode reaction is mass transfer limited, in which stirring and operation at higher temperature would increase the current density for a given cell voltage [12]. Successful performance of the electrochemical cell was shown by AECL for 2-3 days of continuous operation with a voltage of $0.7 \mathrm{~V}$ at room temperature. Electrolysis experiments were also conducted by Pennsylvania State University (PSU). Experimental studies at the Argonne National Laboratory (ANL) showed that Nafion-based and porous polyethylene (PPE) membranes can inhibit copper transport with $\mathrm{HCl}$ as a catholyte [13]. It was demonstrated that the current efficiency is more than $95 \%$ when the cell potential is stable at $0.7 \mathrm{~V}$, and the current density is $0.5 \mathrm{~A} . \mathrm{cm}^{-2}$ for a 36 hour test using a customized Nafion-based membrane. The effects of operating parameters including $\mathrm{HCl}$ and $\mathrm{CuCl}$ concentrations, applied current density, temperature, and solution flow rate, on the cell potential and hydrogen production rate have been successfully demonstrated.

For successful operation of the $\mathrm{Cu}-\mathrm{Cl}$ cycle for hydrogen production, it is important to efficiently design intermediate processes of integration of the main steps. A lab-scale $\mathrm{CuCl} / \mathrm{HCl}$ electrolysis process was designed, fabricated and tested at the University of Ontario Institute of Technology (UOIT). An in-situ methodology for verifying the measured cell voltage during $\mathrm{CuCl} / \mathrm{HCl}$ electrolysis was achieved. The cell voltage measured by the galvanostatic technique was averaged and found to be $0.805 \mathrm{~V}$. The data also shows that the activation overpotential and the voltage drop due to the cell resistance account for about $74 \%$ of the cell voltage. A single-cell experiment under ambient pressure conditions was conducted in order to further understand the electrolyser performance. During a successful 1,600 h long-term test [6], an attempt was made to verify the experimentally measured cell voltage by applying independent electrochemical 
techniques. As a result, the cell impedance was measured under non-steady state operating conditions. Subsequently, a new methodology was developed to verify the experimentally measured cell voltage.

The $\mathrm{Cu}-\mathrm{Cl}$ electrolysis process was modified for a hybrid photo-electrolysis process. Fig. 4 shows the variation of hydrogen production rate with the applied voltage for a fixed $\mathrm{CuCl}$ concentration of $53 \mathrm{~g} / \mathrm{l}$. Increasing the light intensity by $25 \%$ results in a $12.5 \%$ increase of production. This confirms the beneficial effect of direct light input on photoelectrolysis. The anodic overpotential accounted for more than 60\% of the cell voltage. When no voltage is applied from an external source to the electrodes, the experimental results showed that the hydrogen generation rate was approximately $0.3 \mu \mathrm{g} / \mathrm{s}$. The increase of hydrogen production rate is non-linear and enhanced by higher intensities. The photocatalytic effect increased by 32\% when titanium dioxide nanoparticles were added in the anolyte and illuminated. The nanoparticles act as photocatalysts in the photo-electrochemical cell.

The integration of unit operations of the $\mathrm{Cu}-\mathrm{Cl}$ cycle requires the effective control and design of multiphase processes including liquid/solid, bubble/liquid, and solid/gas flows of various sub-processes. It is noted that a significant part of the crystallization occurs within minutes of the formation of the first crystal, around which the growth occurs. An experimental apparatus to investigate dissolution rates of solid $\mathrm{CuCl}$ in aqueous $\mathrm{HCl}$ in the $\mathrm{Cu}-\mathrm{Cl}$ cycle was designed and built at UOIT. From the experimental results, it was found that for a higher concentration of aqueous $\mathrm{HCl}$ and temperature of operation [15], there was a faster rate of dissolution of solid $\mathrm{CuCl}$. One possibility for integration is to first quench the $\mathrm{CuCl}$ overflow from of oxygen reactor to obtain a CuCl-water slurry. This process has been studied by a research group at UOIT for heat recovery purposes such that the molten $\mathrm{CuCl}$ quenched in water generates steam as needed in the hydrolysis reactor. Since the temperature of the $\mathrm{Cu}-\mathrm{Cl}$ water slurry is dependent on heat transfer in the quenching process, the temperature of $\mathrm{HCl}$ is significant so that the desired ternary solution temperature is obtained for improved efficiency of electrolysis.

An experimental apparatus was also designed and built at UOIT to better understand the flow physics of gas-liquid systems as they occur in the oxygen production and electrolysis processes (Fig. 5). The experimental loop examines bubble dynamics through different fluids as well as the amount of mass transferred from the liquid to the gas that is carried out to the surface of the liquid, while the bubbles are rising. Due to the motion of a bubble through water, some of the water molecules from the liquid diffuse across the boundary of the bubble and they are carried out of the water column. The images were then processed in order to obtain the diameter, area, shape, position and velocity of the bubbles.

New solubility data for the copper chloride salts in the $\mathrm{CuCl}-\mathrm{CuCl}_{2}-\mathrm{HCl}-\mathrm{H}_{2} \mathrm{O}$ system was obtained at the temperature range of $30-60^{\circ} \mathrm{C}, \mathrm{CuCl}_{2}$ concentration of 1-2 molal, and $\mathrm{HCl}$ concentration of 5-10 molal. 
In Fig. 6, when the two ternary systems are considered, i.e. $\mathrm{CuCl}-\mathrm{HCl}-\mathrm{H}_{2} \mathrm{O}$ and $\mathrm{CuCl}_{2}-\mathrm{HCl}_{-} \mathrm{H}_{2} \mathrm{O}$, the solubility of $\mathrm{CuCl}$ increases with increasing $\mathrm{HCl}$ concentration, whereas the solubility of $\mathrm{CuCl}_{2}$ decreases with increasing $\mathrm{HCl}$ concentration up to a minimum value, and starts to increase again. Two regions can be identified in this case; the first at $\mathrm{HCl}$ concentrations below 8 molal, where the solubility of $\mathrm{CuCl}$ is lower than that of $\mathrm{CuCl}_{2}$, and the second at $\mathrm{HCl}$ concentrations above 8 molal. These regions determine the thermodynamic limits of the electrolysis step for the two ternary systems. This implies that the solubility of $\mathrm{CuCl}$ is not affected significantly by the presence of $\mathrm{CuCl}_{2}$ at saturation, but the solubility of $\mathrm{CuCl}_{2}$ is depressed in the presence of $\mathrm{CuCl}$ at saturation. Maintaining a low $\mathrm{CuCl}$ concentration in the electrolyser, moderate $\mathrm{HCl}$ concentration and high temperature, ensures that there is no premature crystallization of $\mathrm{CuCl}_{2}$ at the anode side.

It can be inferred from Fig. 6 that with the addition of $\mathrm{CuCl}_{2}$, the solubility of $\mathrm{CuCl}$ in $\mathrm{HCl}$ solutions increases slightly but the addition of $\mathrm{CuCl}$ significantly decreases the solubility of $\mathrm{CuCl}_{2} \cdot 2 \mathrm{H}_{2} \mathrm{O}$. The presence of unreacted $\mathrm{CuCl}$ in the electrolysis promotes the selective crystallization of cupric chloride. Simulations suggest lower values of cupric chloride solubility at a temperature range of 20 up to $80^{\circ} \mathrm{C}$. The individual major processes of the $\mathrm{Cu}-\mathrm{Cl}$ cycle have been investigated and validated. The main technological challenge is the integration of sub-processes and optimizing flow rates to minimize heat requirements. Researchers are investigating advanced material and fabrication techniques to ensure safe material handling for fluids and solids at high temperatures. The application of the $\mathrm{Cu}-\mathrm{Cl}$ cycle has also been extended to work with other industrial process such as cement manufacturing and steel industries. The long-term objective of the research program is eventually integrating the $\mathrm{Cu}-\mathrm{Cl}$ cycle with Canada's generation IV nuclear reactors.

\section{China}

Researchers from China have made significant advances on the development of the sulfur-iodine (SI) cycle for hydrogen production. The design of the system relies on high temperature heat input such as from a Generation IV nuclear reactor. This is similar to the approach in the previous section for Canada. The high temperature gas-cooled reactor-pebble bed module project (HTR-PM Project) in China aims to build a 200 MW modular HTR commercial demonstration power plant in around 2017. The project is supported by the government, in the framework of the "national mid to-long term science / technology plan” for the period 2006-2020.

The HTR cycle has an outlet temperature of $750^{\circ} \mathrm{C}-1000^{\circ} \mathrm{C}$ which can support the SI-cycle's heat requirement $\left(800^{\circ} \mathrm{C}\right)$. The schematic of the operation of the system being proposed by researchers at Tsingua 
University is shown in Fig. 7. Large-scale hydrogen production using the proposed S-I cycle is very efficient does not emit $\mathrm{CO}_{2}$, when combined with renewable energy heat sources such as a Generation IV nuclear reactor. The high temperature electrolysis (HTE) process uses a modular stack design, which is flexible and suitable for various scales of hydrogen production.

The national energy program has priorities including the following areas: technologies for energy savings and efficiency improvement; reasonable, efficient, economic and clean utilization of coal; technological systems for oil supply security; advanced nuclear technologies; advanced and reliable electricity transport and distribution systems; technologies for large-scale utilization of renewable energies; hydrogen and fuel cell technologies. The energy generation from nuclear power is only about $0.93 \%$ of all energy generation methods in China as reported in 2011. In China, a10 MW high temperature gas cooled reactor (HTR-10) was used to demonstrate the capacity of the HTR by reaching full power operation in 2003. This design was extended as shown in Fig. 8

The various phases of research activity are shown in Fig. 9. The long-term objectives for reaching the IS -100 capacity was to achieve stable operation of a closed S-I cycle by demonstrating the process by 2014. The capacity of the hydrogen demonstration system is expected to be approximately $100 \mathrm{NL} / \mathrm{h}$. Some materials critical to the operation of the system include advanced materials such as quartz, teflon, and titanium-tungsten alloys. The research group at Tsingshua University is developing an optimized flow sheet for the system operation, and determining critical parameters (temperature, flowrate, interface, and pressure) for measurement and control. The operation of the system is being considered as a standalone system, which could be used with other high temperature heat sources. Aspen-plus with an OLI database was used to simulate the system performance. Empirical models of EED/Hix distillation were built based on experimental results and embedded in Aspen-plus. The simulation for the overall system was successfully conducted.

A 3-cell short stack with active areas of $5 \mathrm{~cm} \times 5 \mathrm{~cm}$ has been successfully operated. Recently, the development of multiple-cell stacks of $10 \mathrm{~cm} \times 10 \mathrm{~cm}$ cells has been achieved. Advances in SOEC stack structure design, sealing technologies, interconnect coatings, and thermal cycle assessment have been demonstrated. The results from the cell test performance are reported in Table 1. The 10-cell stack performed best of all lab-scale experiments. Fig. 10 reports the effect of voltage and current density on the operation of the S-I cycle. Above 10 hours of operation, an increase in current density and voltage is observed for each hour of operation. The scaling of coupling technology and heat exchanger design remains a technical challenge for the project scale-up. The next phase of the project will investigate a 60-cell stack design. 
The HTR technology presents promising prospects in China. The program provides unique support for the development of nuclear hydrogen production. The nuclear hydrogen program (IS and HTE) and project target of 60L/h is showing significant progress in the S-I cycle development. Successful research and development on the key technologies coupled with Chinese HTR-10 should significantly promote the advancement of other national programs on nuclear hydrogen development. More international cooperation for the development of nuclear hydrogen technology is underway.

\section{France}

Researchers in France have focused on high temperature steam electrolysis (HTSE) for large-scale demonstration projects of hydrogen production. The project plan spans over 12 years as shown in Fig. 11. Commissariat à l'Energie Atomique et aux Energies Alternatives (CEA) is currently testing the 25-cell stack to optimize the system operating parameters. The design of the electrolysis stacks was able to increase performance, durability, and reliability. The results from experiments indicate the system design is robust and the data is reliable and reproducible. To increase the durability, further research is required on cell coatings. One of the current goals is to decrease the cost, while maintaining a high system performance and durability. Experimental results for the 3-cell stack are reported in Fig. 12, which show good performance. A current density of $1.9 \mathrm{~A} / \mathrm{cm}^{2}$ was achieved at about $1.3 \mathrm{~V}$. Very low scattering was observed between cells. Design criteria of low weight and integration of advanced cells were achieved and validated. A promising degradation rate of 1.9 to $3.6 \% / 1000 \mathrm{~h}$ was achieved. One thermal cycle was successfully applied and the sealing solution performed well.

The possibility to achieve very fast transients with no additional degradation upon transients indicates (Fig. 13) coupling with intermittent renewable energies is possible. A low-weight stack was tested several times at the scale of 10 to 25-cells. Design and manufacturing steps were performed to simplify the assembly (easier and quicker, with some already automated steps) and promote reliability. About $1.7 \mathrm{Nm}^{3} / \mathrm{h}_{\text {of }} \mathrm{H}_{2}$ was produced in the 25-cell stack. Very low scattering occurred between different cells with 100\% gas tightness. Good performance was achieved for the 25-cell stack with a current density of $1.8 \mathrm{~A} / \mathrm{cm}^{2}$ at $1.2-1.3 \mathrm{~V}$. When the flow rate increased, a power consumption of 5.6kW was observed in the 25-cell stack. The hydrogen was produced at $1.88 \mathrm{Nm}^{3} / \mathrm{h}$ with an efficiency of $3 \mathrm{kWh} / \mathrm{Nm}^{3}$. This amounts to a stack cost reduction of about $85 \%$ between a robust reference stack and a low-weight stack. The hydrogen market cost is expected to decrease to $2.5 € / \mathrm{kg} \mathrm{H}_{2}$, due to the improvement of stack performance and durability. Table 2 shows a comparison of the HTSE with other existing commercial technologies for producing hydrogen. 
The performance of the 10 and 25-cell stacks is close to those measured in steam electrolysis (even for an inlet gas composition 45 vol. $\% \mathrm{H}_{2} \mathrm{O}+45$ vol. $\% \mathrm{CO}_{2}+10$ vol. $\left.\% \mathrm{H}_{2}\right)$. A current density of $0.8 \mathrm{~A} / \mathrm{cm}^{2}$ was achieved at $1.15 \mathrm{~V}$ with a conversion rate of $52 \%(0.92 \mathrm{~kW})$ with $100 \%$ gas recovery at the outlet. The production rate of hydrogen including carbon monoxide was $0.34 \mathrm{Nm}^{3} / \mathrm{h}$ at $80 \mathrm{~A}$, with an oxygen production rate of $0.17 \mathrm{Nm}^{3} / \mathrm{h}$. The experiments were validated using numerical simulations and good agreement was observed as indicated in Fig. 14. At the stack level, the expected $\mathrm{H}_{2} / \mathrm{CO}$ product ratio was around 3 to produce methane. No accelerated degradation was observed upon reversible operation. The results indicate HTSE is a promising technology for increased performance and decreased $\mathrm{H}_{2}$ production cost compared to other electrolysis technologies. The cell stacks can be operated in co-electrolysis mode. Upscaling activities are in progress including designing larger cell stacks and improving system performance. The research group is also pursuing energy storage applications such as co-electrolysis.

\section{Germany}

Researchers in Germany are leading a European effort to produce hydrogen using solar integrated pressurized high temperature electrolysis (SOPHIA). In the framework of the European project SOPHIA, DLR collaborates with the companyies HyGear B. V. (specialists on Electrolysers, Fuel Cell and Reforming Units, Hydrogen related Separation Techniques, Netherlands), GDF SUEZ (large scale gas producer and provider, France), HTceramix SA (SME with expertise in SOFC and SOEC development, Switzerland), SOFC power SpA (SME with expertise in SOFC and SOEC component manufacturing, Italy) as well as with the hydrogen production research groups from CEA (France), EPFL (Switzerland), and VTT (Finland).

The project is funded by the Fuel Cell and Hydrogen Joint Undertaking (FCH JU) which focuses on the demonstration of a high temperature electrolyzer with a few $\mathrm{kW}$ target scale. A 3 kWe-size system will be developed, built together with all necessary peripheral units, and operated using solar energy for proof of principle. Flow charts will be provided to evaluate a future scale-up of solid-oxide high temperature electrolysis (SOE) plants at a MW scale.

In the European project SOPHIA, hydrogen will be produced from water and electricity by HTSE. The HTSE system will be coupled to a concentrated solar energy source, which will provide the heat required. The combination of hydrogen production by high temperature electrolysis and solar thermal energy sources is very attractive as it creates a synergy. The benefit includes carbon-free technology for hydrogen production and an option for short to long-term storage of electricity, hence simplifying market penetration of renewable carbon-free energy. 
The researchers in Germany have successfully demonstrated the proof-of-concept of a large area stack operating in co-electrolysis, flowcharts for the prototype process, and a segmented test bench for SOEC SRU (Solid Oxide Electrolyzer Cell Single Repeating Unit). With the Clean-Energy partnership (CEP) project in Berlin, Germany has currently the largest and most technologically advanced hydrogen demonstration project in Europe. The national innovation program for hydrogen and fuel cell technology (NIP) is divided into three program areas in order to bring the numerous applications of hydrogen to the front and to address specific market-specific challenges in market preparation. These areas include: transport and hydrogen infrastructure; stationary energy supply in domestic and industrial domains; and special markets (IT / telecommunications, logistics, and fuel cell applications in the leisure/tourism sector).

The merger CEP has set itself a goal to demonstrate the practicality of hydrogen as an alternative fuel in vehicles and to test the infrastructure of hydrogen fueling stations. The CALLUX project objective is to develop existing technology towards reliable and roadworthy systems in the area of domestic energy through the purchase, installation and operation of 800 fuel cell heating equipment units. The NEED project goal is the development of standardized fuel cell systems in combination with biomass recycling plants (biogas, sewage gas, pyrolysis, synthesis) in the field of industrial plants to supply energy. The project aims to use fuel cells for energy supply on-board large ships and ferries. The Bodensee project is investigating the power supply of recreation vehicles (RVs, caravans, boats, and light vehicles) by means of fuel cell systems. Applications of fuel cells in uninterruptible power supply using hydrogen are also being investigated in Germany.

In the view of the dependency on oil and gas imports that are becoming more expensive and climate protection aspects, nuclear process heat and nuclear hydrogen generation is anticipated to experience a "renaissance" in Germany. The technologies which are required for this were developed in Germany up to pilot-scale with the help of public funds. The former German project "Prototype Nuclear Process Heat (PNP)" was virtually a "VHTR" ready for hydrogen generation via coal gasification. A significant effort is being devoted to safeguard the acquired knowledge on systems, procedures, and components for the use of nuclear process heat, in particular for hydrogen production, due to the large market for hydrogen.

The 3 kWe-size pressurized HTSE system cells are optimized for a large-scale area for HTSE. The stack is specifically designed for pressurized operation, integrating the optimized cells. This approach will be complemented by the use of advanced imaging technologies to obtain and exploit an in-depth understanding of the aging mechanisms in pressurized stacks at high temperatures. For the coupling of the HTSE with the solar thermal energy source, a solar receiver will be used in which steam will be generated and fed into the HTSE. The system will be tested at the high-flux solar simulator of DLR in Cologne in order 
to prove the functionality of the system. The concept of co-electrolysis of $\mathrm{CO}_{2}$ and $\mathrm{H}_{2} \mathrm{O}$ to produce syngas will be proved at the stack level.

Additionally, SOPHIA identifies different “power to gas” scenarios of a complete process chain (including power, heat, and $\mathrm{CO}_{2}$ sources) for the technological concept development and its end products valorization. A techno-economic analysis and a life cycle analysis with respect to environmental factors will be carried out for different case studies identified for concept industrialization. This will allow SOPHIA to have an impact on the technology on the deployment and industrialization scenarios of the technology.

Evaluating experimentally real HTSE systems at a representative scale and operating the system under pressure remains a challenge. Within this project, a larger footprint stack will be developed (200 $\mathrm{cm}^{2}$ vs. $80 \mathrm{~cm}^{2}$ ). Particular attention will be given to tolerating higher pressure differences across the ceramic membrane (microstructural adaptation, cell thickness), applying the same design principles, and materials combination as in the current stack. This will maintain the experience in both durability testing and low cost manufacturing also for the future stack, while opening the scope for MW scale systems based upon $5 \mathrm{~kW}$ stacks. The coupling of the HTSE with the solar thermal energy source still remains a challenge. The receiver system was designed and tested using strict modular construction to allow easy replacement in the case of eventually damaged components.

The European project of solar to hydrogen hybrid cycles (SOL2HY2) funded by the Fuel Cell and Hydrogen Joint Undertaking (FCH-JU) focuses on a combined strategy of the introduction of stepwise, carbon-free thermochemical cycles for a large-scale yet extremely flexible hydrogen production plants, tailored for a specific application site. A multi-stack model electrolyzer will be developed and validated at a laboratory scale. A first demonstration will be carried out at the pilot scale (500 KW) for a solar thermochemical water splitting cycle with new components.

In the European project SOL2HY2, hydrogen will be produced by water decomposition via the Hybrid-Sulfur Cycle (HyS), which will be powered by concentrated solar energy. The HyS cycle was identified as one of the most promising thermo-chemical cycles to produce hydrogen. The HyS cycle is a two-step process, wherein the electrochemical step of the HyS cycle, sulfuric acid and $\mathrm{H}_{2}$ are produced by sulfur-dioxide depolarized electrolysis and in the thermochemical part, sulfuric acid is concentrated and decomposed thermally back to $\mathrm{SO}_{2}$ (circulated) and $\mathrm{O}_{2}$ (vented). The schematic of the hydrogen production cycle is shown in Fig. 15. The main advantage of the HyS electrolysis step is that the anodic reaction $\mathrm{SO}_{2}+$ $2 \mathrm{H}_{2} \mathrm{O} \rightarrow \mathrm{SO}_{4}{ }^{2-}+2 \mathrm{H}++2 \mathrm{e}-$ and cathodic reaction $2 \mathrm{H}++2 \mathrm{e}-\rightarrow \mathrm{H}_{2}$ have a standard potential $\mathrm{E}^{\circ} \sim 0.16 \mathrm{~V}$ which is significantly lower than of conventional water electrolysis $\left(E^{\circ}=1.23 \mathrm{~V}\right)$. This gives a potential to significantly reduce the electrical power required. The most energy-demanding part of the HyS cycle is the decomposition of sulphuric acid. 
In parallel, a new route of production of hydrogen, named the Outotec open cycle (OOC), has been developed by Outotec and Aalto University and will be analyzed. In the latter cycle, hydrogen could be produced together with sulphuric acid and common metals ( $\mathrm{Ni}, \mathrm{Cu}, \mathrm{Zn}$ ) economically and in an environmentally friendly way. As in the HyS cycle, the key stage in OOC is the sulfur dioxide-depolarized electrolysis (SDE). Conventionally, the SDE cell consists of two electrodes and a proton exchange membrane, which allows $\mathrm{H}^{+}$ions to pass through. The electrodes are usually covered with catalysts, mainly made from carbon-supported Pt. Reasonable overpotentials (0.7-0.9 V) might be obtained at current densities of $0.2-0.4 \mathrm{~A} / \mathrm{cm}^{2}$ at $60-80^{\circ} \mathrm{C}$. The $\mathrm{SO}_{2}$ cross-over through the PEM membrane leads to its reduction to elementary sulfur (Pt catalyzes this reaction) and parasitic losses, reducing SDE performance. In the OOC experiments, application of corrosion-protective coating, which acts as a catalyst allowed avoiding Pt use.

In connecting the cycle to a nuclear reactor, in principle only different kinds of heat exchangers are required for integrating the system. A solar heat source offers a broader variety of options. In some solar concepts, the radiation is directly absorbed by the reactants. In other concepts radiation is absorbed by a surface/wall and transformed into thermal energy, which is transferred by heat conduction to a container with the reactants behind that wall. Other concepts make use of inert heat transfer media, which are heated in a receiver and transported to the heat to the reactants - directly by mixing or via heat exchangers. The potential is comparable to the other more independent concept, which concerns the use of heat transfer fluids and heat exchanger reactors.

A prototype receiver-reactor for solar decomposition of sulfuric acid has been designed and simulated and will be subsequently tested in DLR's solar furnace in Cologne to prove the feasibility of the concept, to investigate the process behavior, and to refine available experimental data for design studies and for process simulation. The development of a multi-chamber reactor is of central interest in order to examine the vaporization and $\mathrm{SO}_{3}$ reduction process separately.

Core parts of both chambers are porous SiC ceramics serving both as absorbers for concentrated solar radiation and a reactive zone. One chamber contains a ceramic foam, which is wetted by sulfuric acid. Heat is transferred from the hot surface of the foam to the liquid to vaporize it and provide feed for the second chamber. The second chamber contains a ceramic honeycomb structure coated by a catalyst and heated to temperature above $800{ }^{\circ} \mathrm{C}$ by concentrated sunlight to enable the reduction of $\mathrm{SO}_{3}$. This kind of operation allows the independent optimization of both process steps individually.

A major achievement of the SOL2HY2 project includes: provision of optimized flow sheets of the OOC and Solar-HyS cycles; availability of the validated sulfur dioxide depolarized electrolyzer model; design, realization and test operation of the solar decomposition $500 \mathrm{~kW}$ plant; availability of optimized models for all critical subsystems (the sulfur dioxide depolarized electrolyser, solar to heat conversion 
system, solar to electricity conversion system, the solar-powered acid concentrator and the integrated heat exchanger).

Germany is a leader in Europe in hydrogen and fuel cell technology. With the Clean-Energy partnership (CEP) project in Berlin, Germany currently has the largest and most technologically advanced hydrogen demonstration project in Europe. The National Innovation Program for Hydrogen and Fuel Cell Technology (NIP) is divided into three program areas in order to bring the numerous applications of hydrogen to the front and to tackle specific market-specific challenges in market preparation.

For the short-term integration of solar-power sources, scenarios with new OCC will be performed. A simplified structure, extra revenues from acid sales and highly efficient co-use of the existing plants may drop hydrogen costs by about 50-75\% in comparison with traditional process designs. Besides providing key materials and process solutions, for the first time the whole production chain and flow sheet will be connected with multi-objective design and optimization algorithms ultimately leading to hydrogen plants and technology "green concept" commercialization. DLR specific and main tasks of SOL2HY2 are to prepare, carry out and evaluate the demonstration of the technology, in particular the sulfuric acid decomposition, on a solar tower. For this purpose the research platform of the DLR owned solar tower Julich will be used.

The major challenge in the HyS cycle remains in dealing with materials (electrolyzer, concentrator, acid decomposer/cracker and plant components) and with the whole process flow sheet optimization, tailored to specific solar input and plant locations. The previous research projects have brought some solutions for these challenges, but were unable to present a consolidated, optimized plant, and process design incorporating imposed costs, operational constrains, and the whole process chain objectives. Another challenge is to secure $\mathrm{H}_{2}$ and plant costs. Whereas investments might be much lower in OOC, the long-term O\&M costs of the solar-driven plants are not yet known.

\section{Poland}

Researchers at Warsaw University of Technology (WUT) and the Institute of Power Engineering (IPE) are investigating power generation using micro carbonate fuel cells (MCFC) and solid oxide fuel cells (SOFC) fueled by hydrogen. A pre-pilot laboratory research project on $\mathrm{CO}_{2}$ separation using molten carbonate fuel cells considering all the secondary aspects including existence of contaminants in gases fed both to the anode and to the cathode chambers are being investigated at WUT. The MCFC was tested with different synthetic gas compositions corresponding to various conventional power plant flue gases. Numerical models were developed for predicting fuel cell operating parameters. Connected technology such 
as hydrogen tank filling was analyzed. Single cells were operated and analyzed with a capacity to scale up the experiments to $1 \mathrm{~kW}$ stacks of cubic design (square cells). Further investment is required to construct the first $\mathrm{CO}_{2}$ separation pilot plant based on MCFC. The pre-pilot scale is investigating $\mathrm{CO}_{2}$ separation performance and its optimization with the presence of contaminants in supplied gases. The occurrence of dust particles and $\mathrm{SO}_{\mathrm{x}}$ in cathode feed is also being investigated. Hydrogen is produced by an electrolyzer with the pressure ranging up to 4 bars.

The IPE fuel cell group is focused on full-scale systems, including pilot and demonstration systems. Three systems are being demonstrated on SOFC system capabilities. The three systems are a $1.6 \mathrm{~kW}$ microCHP system incorporating a steam reformer of a renewable fuel (National Strategic Research Programme), $10 \mathrm{~kW}$ system for a telecommunication station (FCH-JU project ONSITE), and a $2 \mathrm{~kW}$ CCHP unit with carbon capture and separation using algal biofixation (FCH-JU project SOFCOM). Laboratory work is mostly addressing technical aspects of SOFC, including evaluation of operating strategies, alternative fuels and fuel processing methods, and carbon formation and deposition. The Fuel Cell Group of the Institute is focused on solving technical challenges of limiting application cells and systems. These are related to effects of various contaminants, fuel, and compositions. Activities related to fuel cell stacks are addressing reliability issues, gas tightness, thermal balancing, and integration.

The development of short stacks is on-going with an emphasis on gasket fabrication. In total, seven test stands were designed specifically for single cell, short- and full-scale stacks in operation. Hydrogen production via steam reforming is the main focus of the Fuel Cell Group. The thermal process division has developed a novel design of a biomass gasifier capable of producing hydrogen-rich gases for several applications, including feeding an SOFC stack. In 2014, online operation of the gasifier and a commercial SOFC stack was developed. Alternatively, hydrogen is supplied at high pressure in tanks on a commercial basis.

In Poland, the country is a partner of the FCH-JU project, which is being led by Germany. Although WUT is not a partner in the FCH-JU project, funding partners are actively being sourced parallel to the FCHJU project. Present challenges include regulations disparity, price of energy from fuel cell applications not reaching market parity, and clear understanding for the current and future financial support or subsidies remains unclear. The expected milestones within the next five years are construction of the SOFC stack, market-ready SOFC micro-CHP units, and development of the DC-SOFC stack. In addition, the development of an electrolysis stack will be initiated in this period. 


\section{Romania}

The National Hydrogen and Fuel Cell Centre (NHFCC) is the body of the Romanian National Authority for Scientific Research for developing and implementing new technologies related to the hydrogen energy. The mission of NHFCC is to facilitate, prove, and accelerate the development and deployment of fuel cell technology and fuel cell systems; promote strategic alliances to address the market challenges associated with the installation and integration of fuel cell systems; and to educate and develop resources for the various stakeholders in the fuel cell community. NHFCC is a full member in the Research Group of the Joint Technology Initiative - Joint Undertaking on Hydrogen and Fuel Cells. The membership agreement guarantees rights in decision making, in defining business strategies and also in the participation to the European calls that will be launched within the FCH-JU.

The NHFCC results expected by 2020 include: obtaining definitive information regarding the catalytic oxidation mechanism, oxygen reduction and proton transport through polymeric membranes by carrying out fundamental and exploratory interdisciplinary research; developing simulation models capable of providing data design for hydrogen processors and fuel cell assemblies; obtaining the first portable fuel cell systems for back-up needs to achieve an integrated system competitive from a cost and characteristics points of view with the existing conventional systems (diesel generators); and building a demonstration system that will generate energy using fuel cells connected to a network.

NHFCC is mandated to handle at a national level the issues related to the basic research, development, testing, outreach and defining national codes and standards related to the production, delivery, storage, and use of hydrogen. The main objectives of NHFCC are: promoting excellence in fundamental and applied research, providing support for development of applied technologies and models, advice and support in taking decisions and carrying out activities for authorities regarding renewable energy in general and hydrogen technologies in particular; and support for training activities for students and young researchers. There are a number of equipment capabilities at NHFCC for testing and validation of fuel cell technology, equipment that is highly specific for creating a national facility to serve the research needs and development in the country. NHFCC currently performs research in modeling, integrating renewable, catalytic membrane reformer design, thermo-chemical water splitting and other cross-cutting issues.

NHFCC currently performs research in integrating renewable energy with water electrolysis for hydrogen "green” production, catalytic membrane reformer design, thermo-chemical water splitting. All are conducted at the experimental laboratory-scale. The potential of the Copper-Chlorine (Cu-Cl) thermochemical cycle for large-scale hydrogen production using nuclear energy is under investigation to perform 
integrated lab-scale (ILS) experiments to demonstrate closed-loop operation of the Cu-Cl cycle. As a result of this activity, the center is a part of an international project named "Clean Hydrogen Production with Water Splitting Technologies”, with Canada as the leader of the project. NHFCC has participated in projects involving the assessment of the potential, and relevant business cases for large scale and seasonal storage of renewable electricity by hydrogen underground storage in Europe - in a HyUnder consortium.

\section{Conclusions}

Although various countries are using different methods for large-scale demonstration projects of hydrogen production from renewable energy, there are significant efforts to develop a hydrogen infrastructure towards a future hydrogen economy. Germany, China, France, and Canada have programs that have made significant strides in moving closer to a demonstration of high temperature processes for producing hydrogen. Poland and Romania have detailed plans of achieving similar objectives. The cooperation of different research groups and countries despite using different technologies will be a significant contributor towards a future hydrogen economy.

\section{Acknowledgements}

Support of this research from Atomic Energy of Canada Limited, Ontario Research Excellence Fund and the Natural Sciences and Engineering Research Council of Canada are gratefully acknowledged.

\section{References}

[1] M.A. Lewis, J.G. Masin, The evaluation of alternative thermochemical cycles-Part II: The downselection process, Int .J. Hydrogen Energy. 34 (2009) 4125-4135.

[2] A. Kettner, L. Stolberg, H. Li, A. Shkarupin, S. Suppiah, Electrolysis Cell with Multiple Membranes for $\mathrm{CuCl} / \mathrm{HCl}$ Electrolysis in Hydrogen Production, Patent Pending, PCT/CA2013/000294. (2013).

[3] W. Kreuter, H. Hofmann, Electrolysis: the important energy transformer in a world of sustainable energy, Int J. Hydrogen Energy. 23 (1998) 661-666.

[4] G.F. Naterer, S. Suppiah, L. Stolberg, M.A. Lewis, S. Ahmed, Z. Wang, M.A. Rosen, I. Dincer, K. Gabriel, E. Secnik, E.B. Easton, S.N. Lvov,V. Papangelakis, A. Odukoya, Progress of international program on hydrogen production with the copper-chlorine cycle, Int J Hydrogen Energy. 39 (2014) 2431-2445. 
[5] Naterer, G.F., Suppiah, S., Stolberg, L., Lewis, M., Ferrandon, M., Wang, Z., Dincer, I., Gabriel, K., Rosen, M.A., Secnik, E., Easton, E.B., Trevani, L., Pioro, I., Tremaine, P., Lvov, S., Jiang, J., Rizvi, G., Ikeda, B.M., Lu, L., Kaye, M., Smith, W.R., Mostaghimi, J., Spekkens, P., Fowler, M., Avsec, J. Clean hydrogen production with the $\mathrm{Cu}-\mathrm{Cl}$ cycle - Progress of international consortium, I: Experimental unit operations. International Journal of Hydrogen Energy (2011) 35: 15472-15485.

[6] G. Naterer, S. Suppiah, L. Stolberg, M. Lewis, Z. Wang, I. Dincer, M. Rosen, K. Gabriel, E. Secnik, E. Easton, Progress of international hydrogen production network for the thermochemical $\mathrm{Cu}-\mathrm{Cl}$ cycle, Int $\mathrm{J}$ Hydrogen Energy. 38 (2013) 740-759.

[7] G.F. Naterer, S. Suppiah, M.A. Lewis, K. Gabriel, I. Dincer, M.A. Rosen, M. Fowler, G. Rizvi, E.B. Easton, B. Ikeda, M.H. Kaye, L. Lu, I. Pioro, P. Spekkens, P. Tremaine, J. Mostaghimi, J. Avsec, J. Jiang, Recent Canadian advances in nuclear-based hydrogen production and the thermochemical $\mathrm{Cu}-\mathrm{Cl}$ cycle, Int. J. Hydrogen Energy. 34 (2009) 2901-2917.

[8] I. Dincer, Green methods for hydrogen production, Int. J. Hydrogen Energy. 37 (2012) 1954-1971.

[9] M.A. Lewis, Update on the Cu-Cl cycle R\&D effort. Workshop of the ORF Hydrogen Project at AECL Chalk River Laboratories, 17 (2008) 25-33-Chalk River, Ontario.

[10] S. Kim, R. Schatz, S. Khurana, M. Fedkin, C. Wang, S. Lvov, Advanced CuCl electrolyzer for hydrogen production via the Cu-Cl thermochemical Cycle, ECS Transactions. 35 (2011) 257-265.

[11] L. Stolberg, Electrolysis cell for the conversion of cuprous chloride in hydrochloric acid to cupric chloride and hydrogen gas. U.S. Patent No. 0051469; 2010..

[12] S. Suppiah, G.F. Naterer, M. Lewis, L. Trevani, E.B. Easton, I. Dincer, Thermo-mechanical design of nuclear-based hydrogen production., In: ORF workshop on nuclear-based thermochemical hydrogen production Oshawa, Ontario. (February, 2011).

[13] M.A. Lewis, S. Ahmed, S. Lvov, C. Fan, II.E.2 Membrane/Electrolyzer development in the Cu-Cl thermochemical cycle, Annual progress report, DOE hydrogen and fuel cells program. (FY 2012).

[14] T.A.H. Ratlamwala, Design, analysis, and experimental investigation of Cu-Cl based integrated systems , PhD Thesis, University of Ontario Institute of Technology. (2013). 
[15] O.A. Jianu, Z. Wang, G.F. Naterer, M.A. Rosen, Constituent Solubility and Dissolution in a CuCl-HCl$\mathrm{H}_{2} \mathrm{O}$ Ternary System. , Experimental Thermal and Fluid Science. (2014) (submitted). 
Table 1: Stack Performance in S-I cycle (2014)

\begin{tabular}{|c|c|c|c|c|}
\hline \multicolumn{4}{|c|}{ Stack performances - Summary (2014) } \\
\hline \multirow{2}{*}{} & \multirow{2}{*}{$\begin{array}{c}\text { ASR } \\
\left(\Omega . \mathrm{cm}^{2}\right)\end{array}$} & \multicolumn{3}{|c|}{$\begin{array}{c}\text { Performance at thermal-neutral } \\
\text { voltage }(1.3 \mathrm{~V})\end{array}$} \\
\cline { 3 - 5 } & $\begin{array}{c}\text { Current } \\
\text { Density } \\
\left(\mathrm{mA}^{2} \mathrm{~cm}^{2}\right)\end{array}$ & $\begin{array}{c}\text { Hydrogen production } \\
\text { rate per cell }(\mathrm{L} / \mathrm{h})\end{array}$ & $\begin{array}{c}\text { Total Hydrogen } \\
\text { production rate }(\mathrm{L} / \mathrm{h})\end{array}$ \\
\hline 1-cell & 0.76 & 500 & 14.7 & 14.7 \\
\hline 3-cell & 1.04 & 370 & 10.9 & 32.6 \\
\hline 5-cells & 2.4 & 185 & 5.4 & 27.1 \\
\hline 10-cells & 2.33 & 204 & 6.0 & 60.0 \\
\hline \hline
\end{tabular}

Table 2: Comparison of cost for various technologies

\begin{tabular}{|c|c|c|c|}
\hline Process & TRL (maturity) & $\begin{array}{c}\text { Investment } \\
\text { cost (eq. Unit } \\
0.2 \mathrm{~kg} / \mathrm{s} \text { ) }\end{array}$ & $\mathrm{H}_{2}$ cost \\
\hline HTSE & 4 & $34 \mathrm{M \epsilon}$ & $3.8 \rightarrow 2.5 \epsilon / \mathrm{kg}$ \\
\hline Alkaline & $7-8$ & $25-30 \mathrm{M} \epsilon$ & $3.0 \epsilon / \mathrm{kg}$ \\
\hline SMR & 9 & $8 \mathrm{M} \epsilon$ & $1.6 \epsilon / \mathrm{kg}$ \\
\hline
\end{tabular}

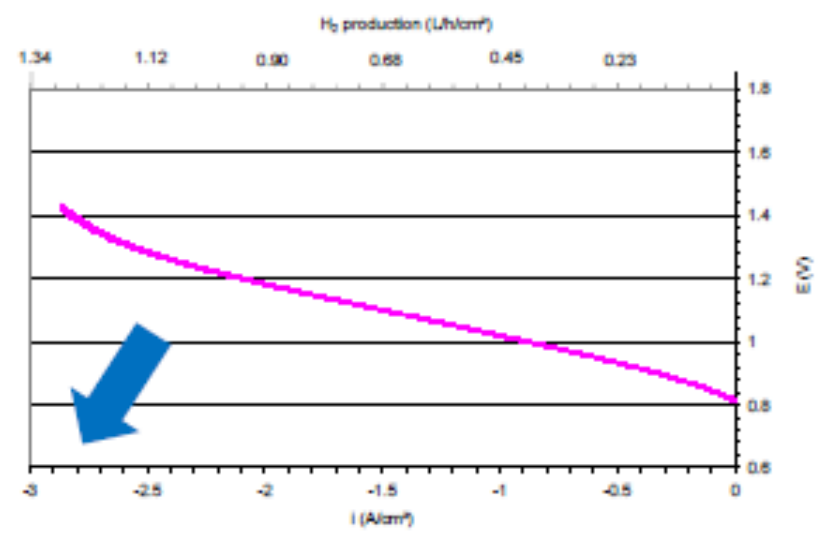

Figure 1: Effect of current density on hydrogen production in electrolytic processes 


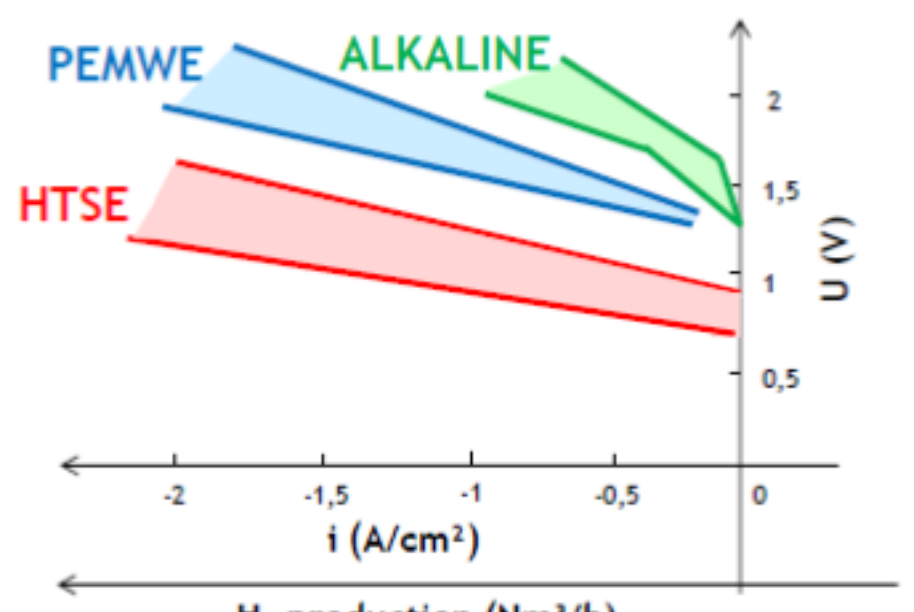

$\mathrm{H}_{2}$ production $\left(\mathrm{Nm}^{3} / \mathrm{h}\right)$

Figure 2: Comparison of operating points of alkaline, PEM, and high temperature steam electrolysis

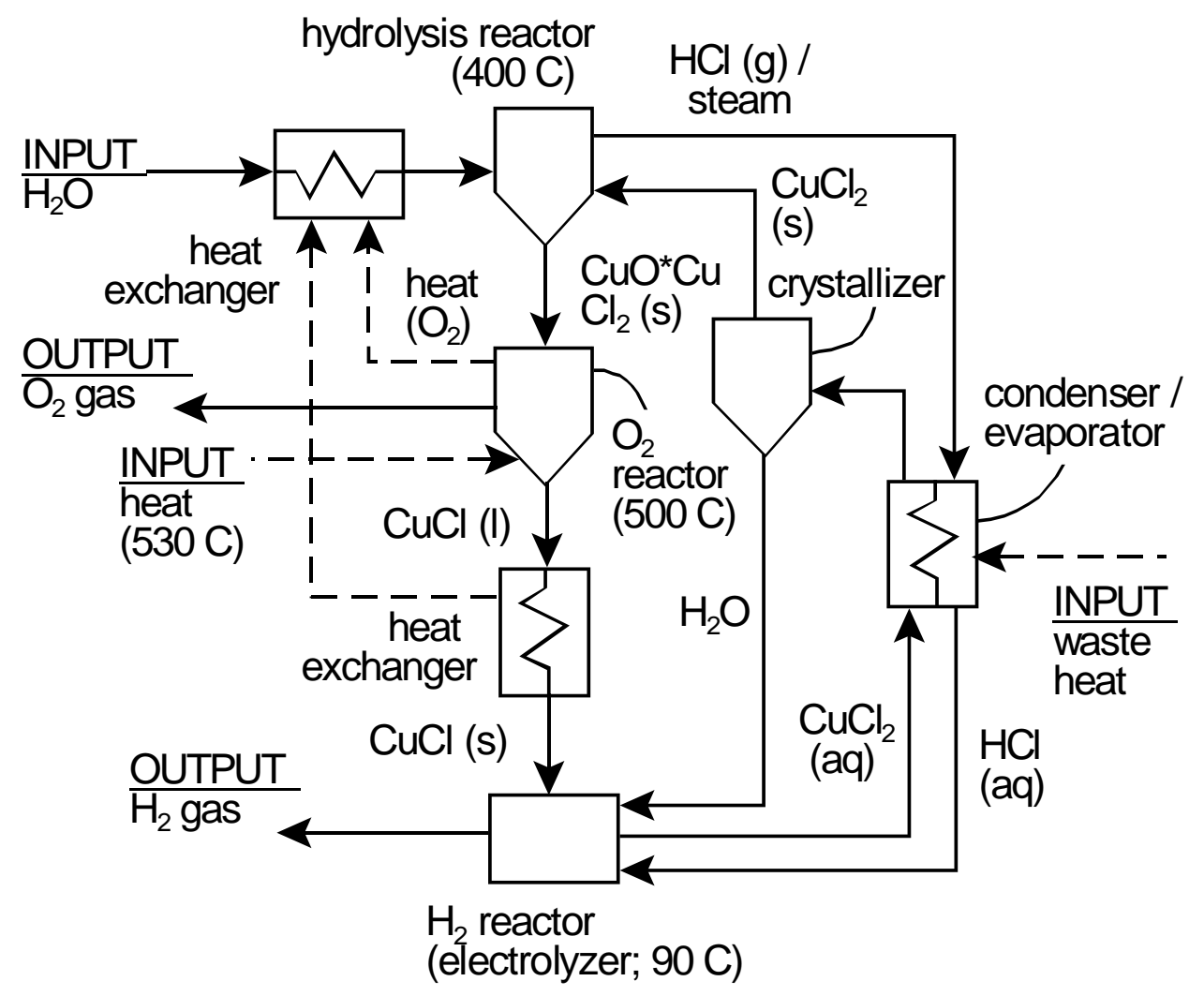

Fig. 3. Schematic of a thermochemical copper-chlorine cycle [7] 


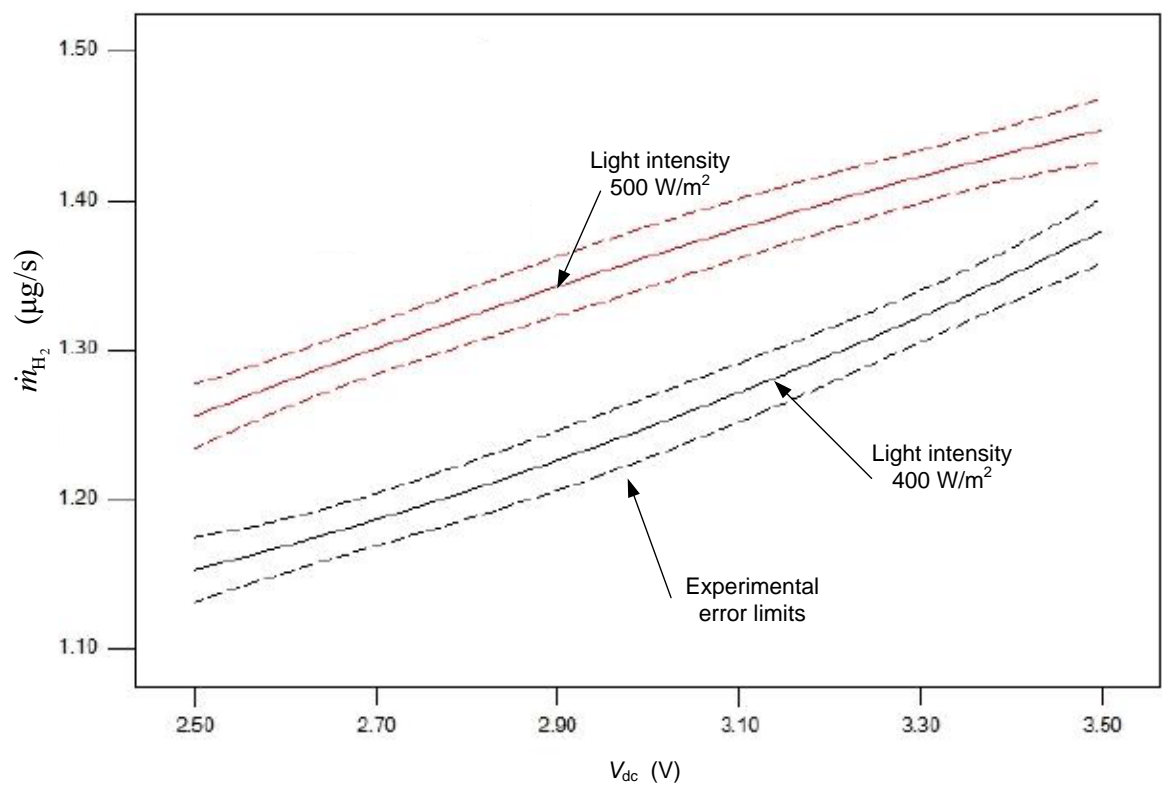

Fig. 4. Effect of light intensity on photo-electrolytic cell $\mathrm{H}_{2}$ production (CuCl concentration 53 g/l [14])

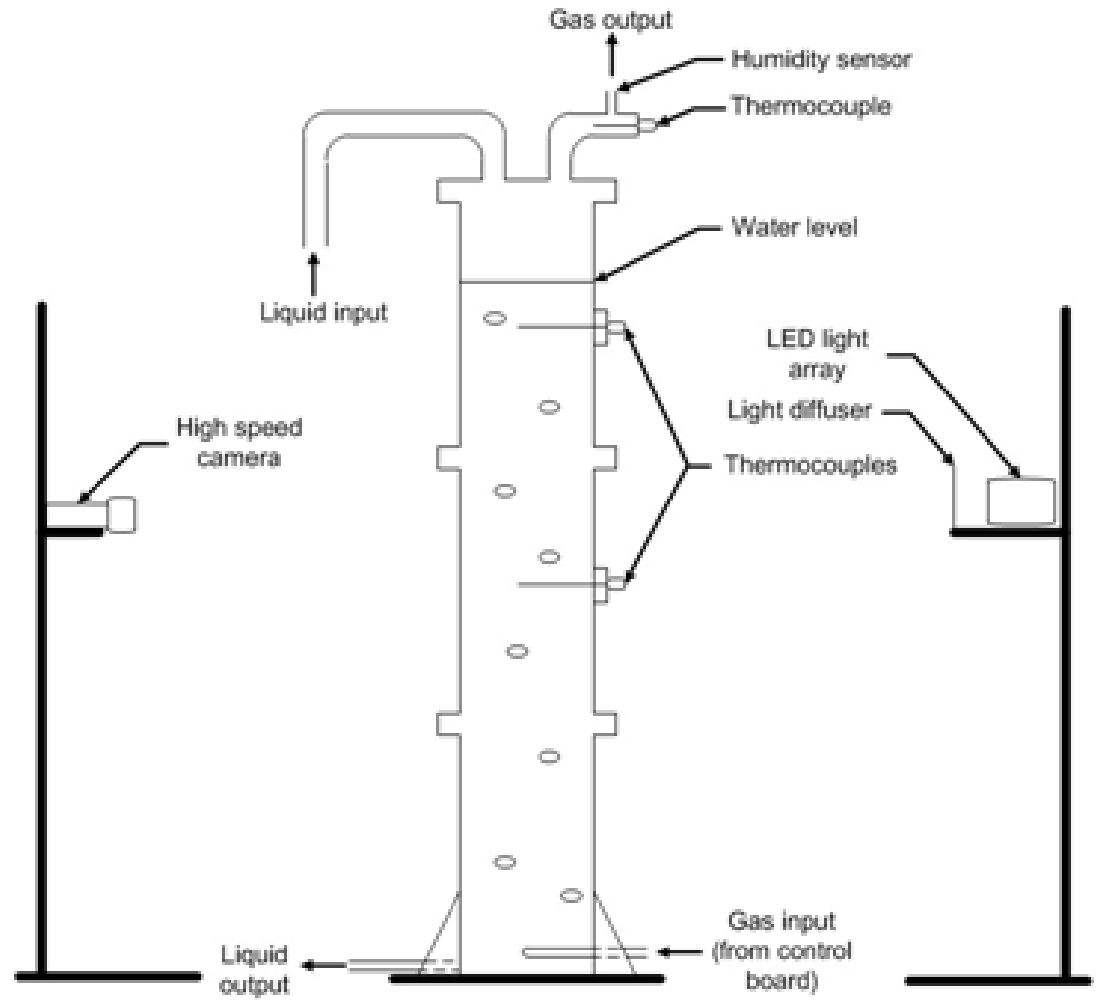

Fig.5. Schematic of gas diffusion experimental apparatus 


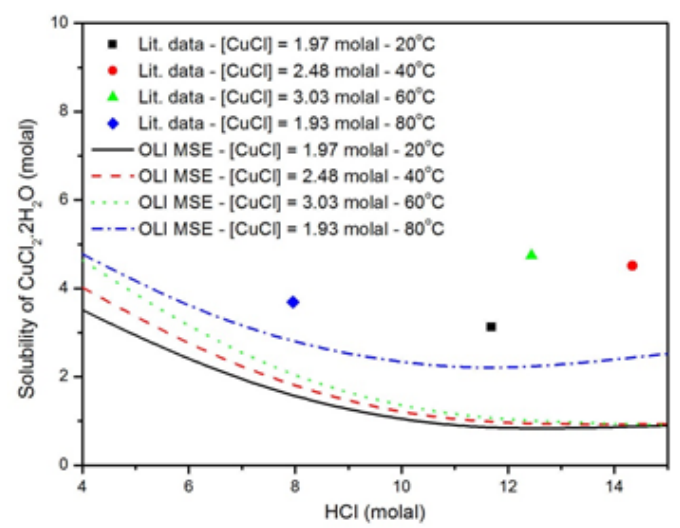

Fig. 6. Comparison between OLI prediction of the solubility of $\mathrm{CuCl}_{2} \cdot 2 \mathrm{H}_{2} \mathrm{O}$ in the quaternary $\mathrm{CuCl}_{2}-$ $\mathrm{CuCl}-\mathrm{HCl}-\mathrm{H}_{2} \mathrm{O}$ solution and past data [4]

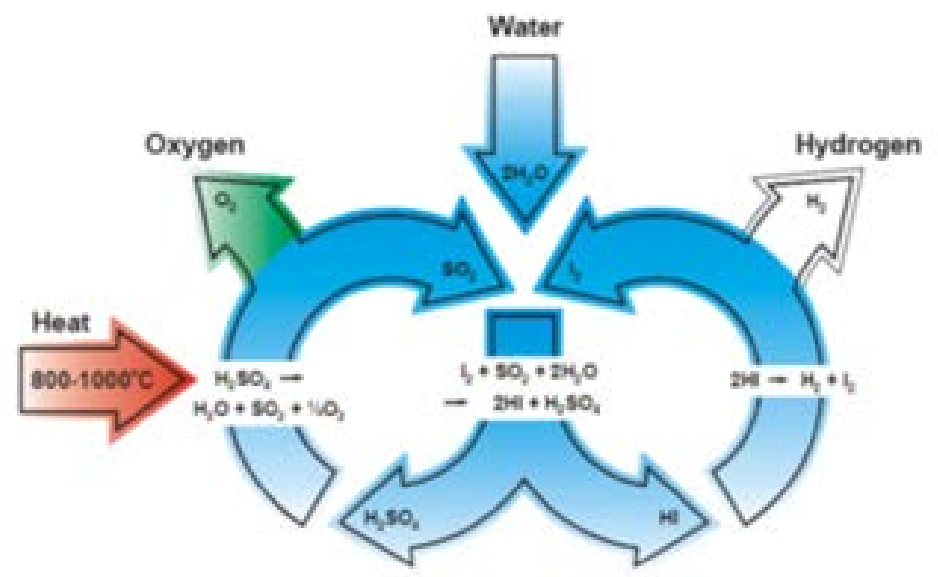

Figure 7: Schematic of Sulfur Iodine (S-I) hydrogen production cycle

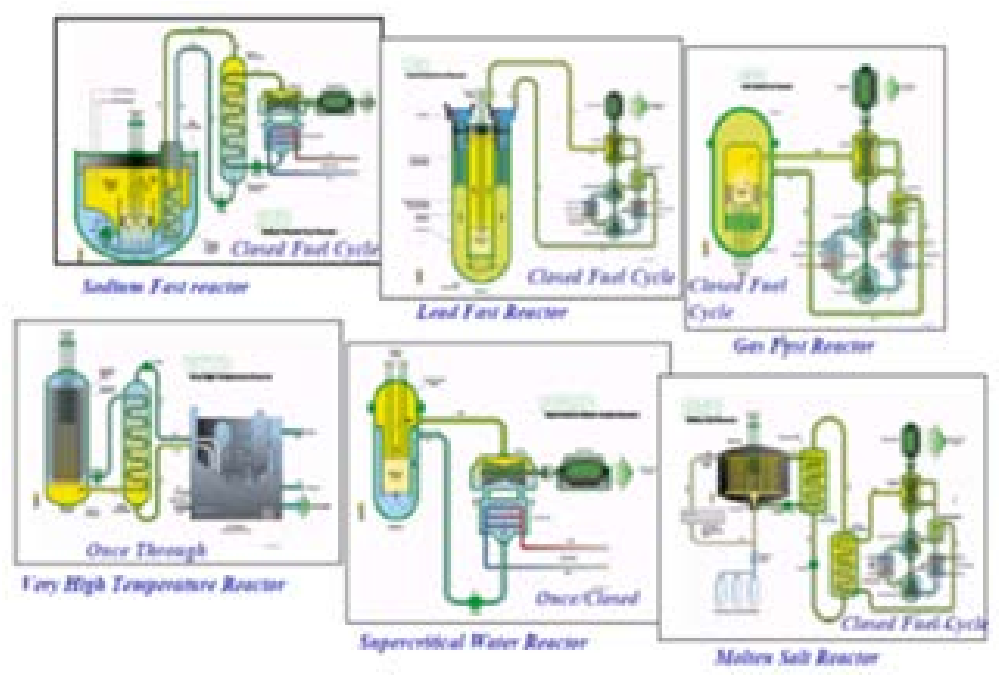

Figure 8: Schematic of integration of S-I cycle with Generation IV nuclear reactor 


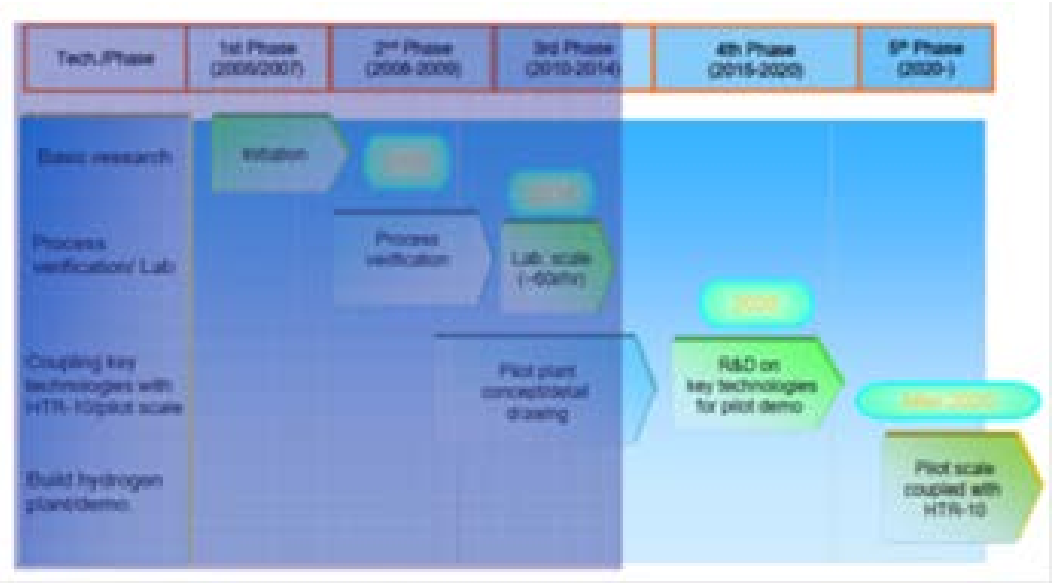

Figure 9: Research plan of nuclear hydrogen development in China

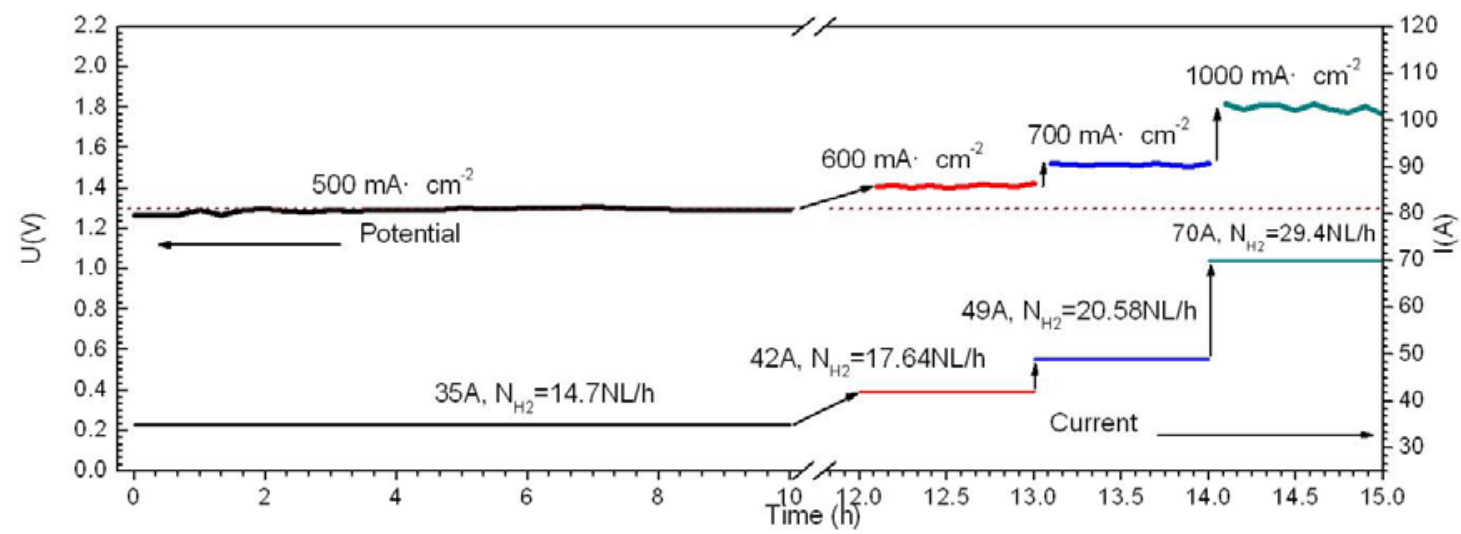

Figure 10: Long term test of operating high temperature electrolytic cell for S-I cycle

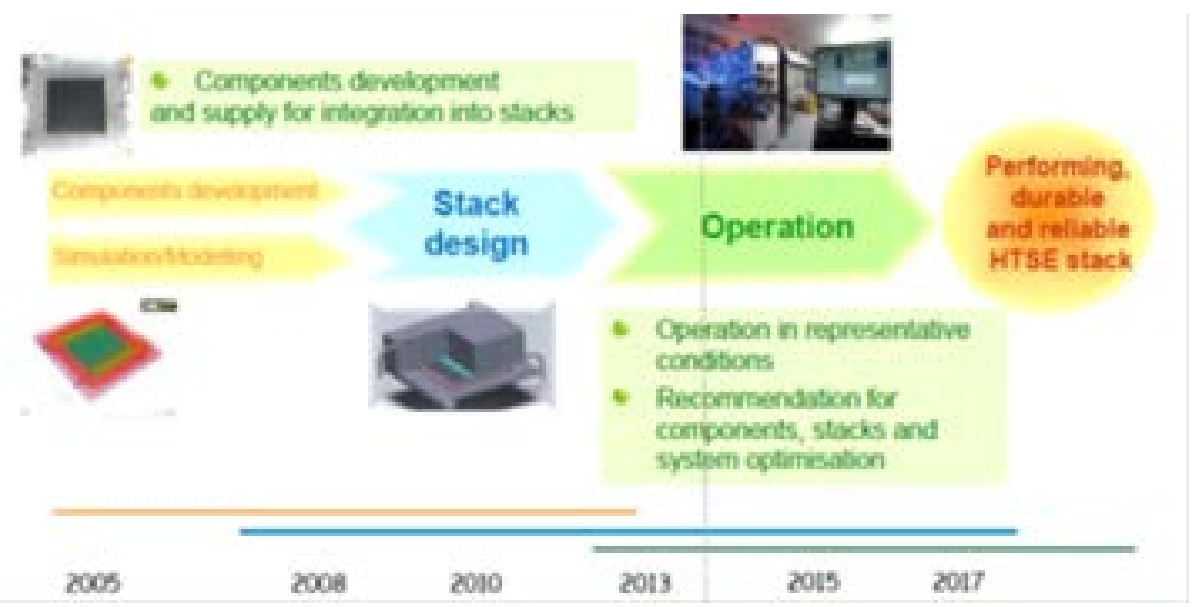

Figure 11: Project plan for developing high temperature electrolysis in France 


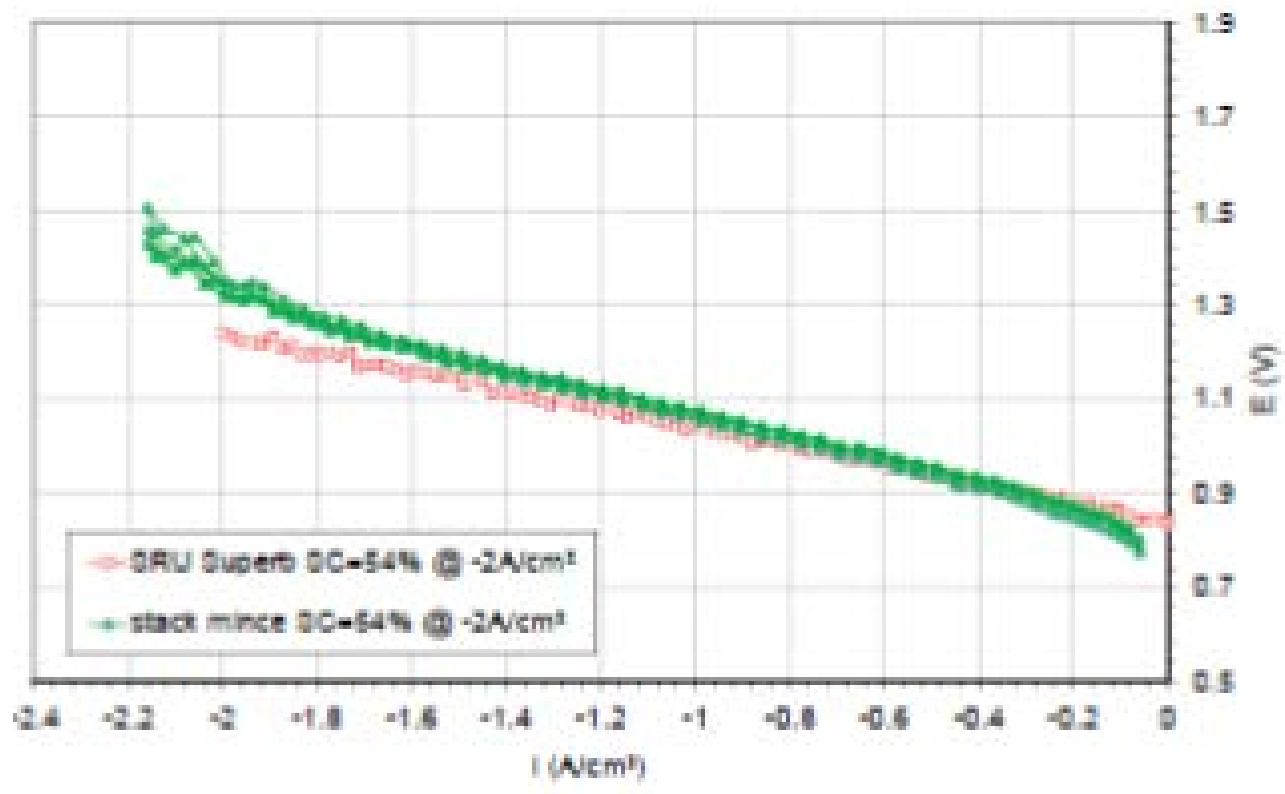

Figure 12: Performance of 3-stack cell at $800^{\circ} \mathrm{C}, 90 \% \mathrm{H}_{2} \mathrm{O} / 10 \% \mathrm{H}_{2}$ on the hydrogen side, air on the oxygen side, $\mathrm{SC}=54 \%$ for $\mathrm{i}=-2 \mathrm{~A} / \mathrm{cm}^{2}$

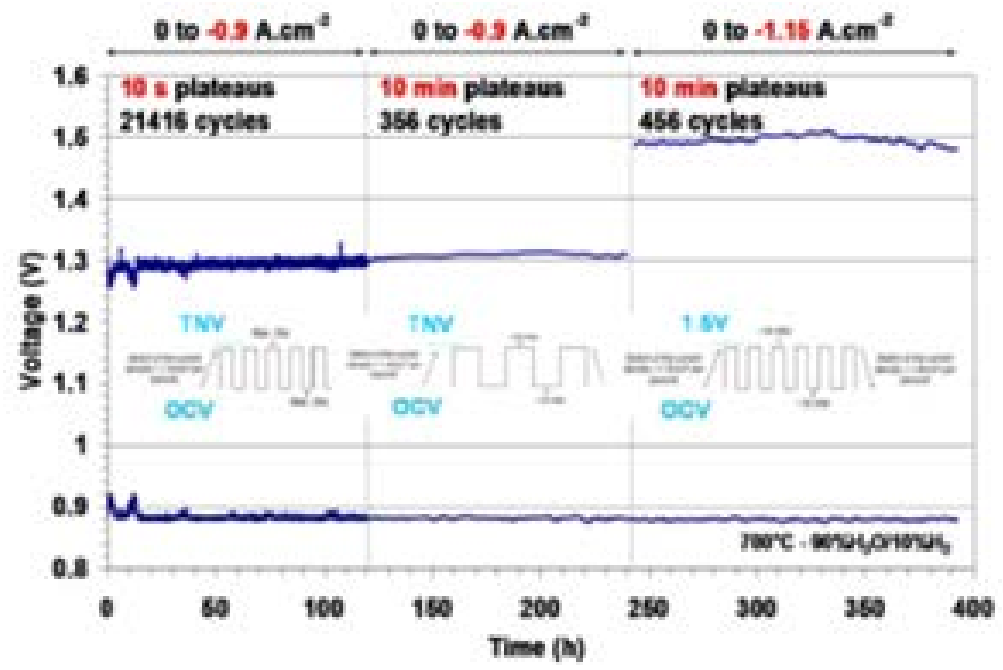

Figure 13: Operation of reference 1-cell stack with advanced cells 


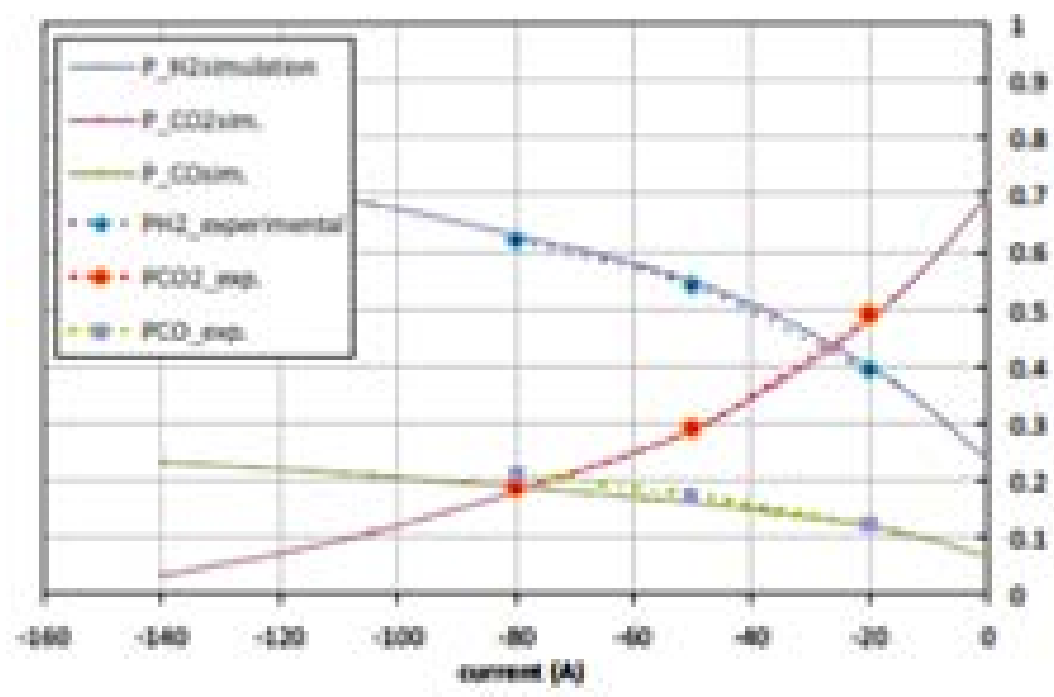

Figure 14: Measurements of the outlet gas composition and comparison to models for the 10-cell stack operating at $800^{\circ} \mathrm{C}$ (cathodic inlet: 65 vol. $\% \mathrm{H}_{2} \mathrm{O}+25$ vol. $\% \mathrm{CO} 2+10$ vol. $\% \mathrm{H}_{2}$ - Conversion rate of oxidized species $=64 \%$ at $-1 \mathrm{~A} / \mathrm{cm}^{2}$ )

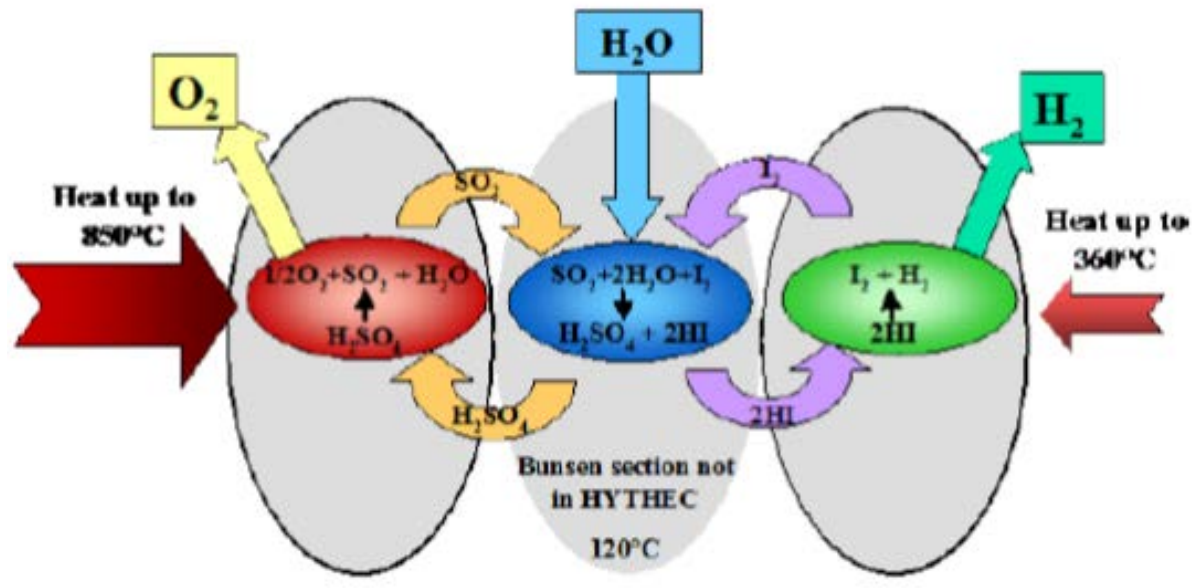

Figure 15: Schematic of HTSE process developed in Germany 